\title{
Article \\ Application of a Clinical Workflow May Lead to Increased Diagnostic Precision in Hereditary Spastic Paraplegias and Cerebellar Ataxias: A Single Center Experience
}

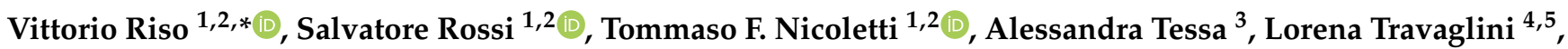 \\ Ginevra Zanni ${ }^{4,5}$, Chiara Aiello ${ }^{4,5}$, Alessia Perna ${ }^{1,2}{ }^{(D}$, Melissa Barghigiani ${ }^{3}$, Maria Grazia Pomponi ${ }^{6}$, \\ Filippo M. Santorelli ${ }^{3}$ (D) and Gabriella Silvestri ${ }^{1,2}$ D
}

Citation: Riso, V.; Rossi, S.; Nicoletti, T.F.; Tessa, A.; Travaglini, L.; Zanni, G.; Aiello, C.; Perna, A.; Barghigiani, M.; Pomponi, M.G.; et al. Application of a Clinical Workflow May Lead to Increased Diagnostic Precision in Hereditary Spastic Paraplegias and Cerebellar Ataxias: A Single Center Experience. Brain Sci. 2021, 11, 246 https://doi.org/10.3390/brainsci 11020246

\section{Academic Editor:}

Alberto Fernandez-Teruel

Received: 15 December 2020

Accepted: 11 February 2021

Published: 16 February 2021

Publisher's Note: MDPI stays neutral with regard to jurisdictional claims in published maps and institutional affiliations.

Copyright: (C) 2021 by the authors Licensee MDPI, Basel, Switzerland. This article is an open access article distributed under the terms and conditions of the Creative Commons Attribution (CC BY) license (https:// creativecommons.org/licenses/by/ $4.0 /)$.
1 UOC Neurologia, Fondazione Policlinico Universitario 'A. Gemelli' IRCCS, 00168 Rome, Italy; salvatorerossi309@gmail.com (S.R.); tommasof.nicoletti@gmail.com (T.F.N.); alessia1perna@gmail.com (A.P.); gabriella.silvestri@unicatt.it (G.S.)

2 Department of Neurosciences, Università Cattolica del Sacro Cuore, 00168 Rome, Italy

3 Molecular Medicine Unit, IRCCS Fondazione Stella Maris, 56018 Pisa, Italy; aletessa@gmail.com (A.T.); mely.b91@hotmail.com (M.B.); filippo3364@gmail.com (F.M.S.)

4 Unit of Muscular and Neurodegenerative Diseases, Department of Neurosciences, Bambino Gesù Children's Hospital, 00165 Rome, Italy; lorena.travaglini@opbg.net (L.T.); ginevra.zanni@opbg.net (G.Z.); chiara.aiello@opbg.net (C.A.)

5 Genetics and Rare Diseases Research Division, Bambino Gesù Children's Hospital, 00165 Rome, Italy

6 UOC Genetica Medica, Fondazione Policlinico Universitario “A.Gemelli” IRCCS, 00168 Rome, Italy; mariagrazia.pomponi@policlinicogemelli.it

* Correspondence: vriso90@gmail.com

\begin{abstract}
The molecular characterization of Hereditary Spastic Paraplegias (HSP) and inherited cerebellar ataxias (CA) is challenged by their clinical and molecular heterogeneity. The recent application of Next Generation Sequencing (NGS) technologies is increasing the diagnostic rate, which can be influenced by patients' selection. To assess if a clinical diagnosis of CA/HSP received in a third-level reference center might impact the molecular diagnostic yield, we retrospectively evaluated the molecular diagnostic rate reached in our center on 192 unrelated families (90 HSP and 102 CA) (i) before NGS and (ii) with the use of NGS gene panels. Overall, $46.3 \%$ of families received a genetic diagnosis by first-tier individual gene screening: $43.3 \%$ HSP and 50\% spinocerebellar ataxias (SCA). The diagnostic rate was 56.7\% in AD-HSP, 55.5\% in AR-HSP, and $21.2 \%$ in sporadic HSP. On the other hand, 75\% AD-, 52\% AR- and 33\% sporadic CA were diagnosed. So far, 32 patients (24 CA and 8 HSP) were further assessed by NGS gene panels, and 34.4\% were diagnosed, including 29.2\% CA and 50\% HSP patients. Eleven novel gene variants classified as (likely) pathogenic were identified. Our results support the role of experienced clinicians in the diagnostic assessment and the clinical research of CA and HSP even in the next generation era.
\end{abstract}

Keywords: NGS; HSP; SCA; hereditary spastic paraplegia; ataxia; neurogenetics

\section{Introduction}

Until a few years ago, the diagnostic route of Hereditary Spastic Paraplegias (HSPs) and cerebellar ataxias (CA) was time-consuming, cost expensive and challenging in many cases because of their clinical and genetical heterogeneity.

So far, at least 64 genes (the SPastic Gait/Gene or SPG genes) have been characterized, and further HSP loci have been mapped [1-7]. Most autosomal dominant (AD)-HSPs are pure, and SPG4, due to mutations in SPAST, is the most common genetic variant [1-3] Mutations in ATL1 (SPG3A), REEP1 (SPG31), and KIF5A (SPG10) are also relatively frequent; when combined with SPG4, these forms account for about $50-60 \%$ of AD-HSP families [8-10]. 
Autosomal recessive (AR)-HSPs are mostly complicated and more heterogeneous than AD-HSP, with at least 50 SPG loci (and 45 causal genes) so far identified [3]. SPG11, due to mutations in the spatacsin gene, is the most frequent form, including about $20 \%$ of all AR-HSP and up to $45 \%$ of AR-HSP with a thin corpus callosum (TCC) [11,12]. Additional genes, including CYP7B1 (SPG5), paraplegin (SPG7), and ZFYVE26 (SPG15) [7-10], totally account for another $20 \%$ of AR-HSP. While X-linked HSPs are extremely rare [1-3], it is noteworthy that specific HSP genes have been recently associated with both AD and AR forms, depending on the effect of the mutations [13-19].

Inherited degenerative cerebellar ataxias (CA or spinocerebellar ataxias, SCAs) include over 100 related genes and all possible modes of transmission [20]. Both the autosomal dominant (ADCAs) and the autosomal recessive variants (SCAR/ARCAs) are numbered in the chronological order in which loci were identified [20]. ADCA usually have an adult onset, and they are most frequently caused by pathological expansions of CAG repeats in seven genes, all encoding for polyglutamine (polyQ) tracts. They globally account for $40-60 \%$ of ADCA cases, whereas about 3-5\% of dominant forms are caused by either non-coding repeat expansions or conventional mutations in further genes [20].

ARCAs usually have an infantile or juvenile onset; their genetic diagnosis is more challenging because of a possible clinical overlap with other rare neurogenetic disorders [21,22]. Sporadic HSP and SCA can also occur, and a genetic etiology is identified in a minority of these patients.

The first significant progress in the genetic and pathogenic characterization of SCAs and HSPs occurred with the identification of the poly-Q repeat expansions as a frequent cause of ADCAs, of pathological GAA expansion in the FXN gene associated with Friedreich ataxia, and of mutations or major rearrangements located in the SPAST gene in association with pure HSP (SPG4).

Molecular screening studies on large cohorts of SCA/HSP patients indicated that such genetic etiologies could account for no more than $30-50 \%$ of the familial cases, with a distinct prevalence in the various populations. In the following years, the identification of many novel SCA/HSP genes confirmed their wide genetic heterogeneity. Thus, the use of individual gene screening required constant updates of the applied diagnostic flowcharts, and eventually became time-consuming, expensive, and applicable only by a few research centers.

The development of Next Generation Sequencing (NGS) technologies has marked a turning point in the diagnosis of HSPs and ARCA/SCAs. NGS analysis by targeted resequencing multigene panels (TRPs) represents the most cost-effective approach, allowing high deep coverage of the coding exons of a variable number of known disease-related genes at once. Additional high-throughput NGS methods are whole-exome sequencing (WES), covering the full set of DNA encoding sequences, and whole-genome sequencing (WGS), representing the most expensive, all-inclusive technique [23].

The use of NGS panels has improved (i) the rate and timing of genetic characterization in HSP and SCA patients and (ii) the definition of the relative prevalence and phenotypic spectrum of individual forms [24,25], also documenting a continuum spastic/ataxic clinical spectrum related to functionally clustered genes [26]. WES or WGS represent an additional turning point allowing the identification of novel SCA/HSP genes, a prerequisite to shed further light on related pathogenic mechanisms and future treatments $[27,28]$.

The diagnostic rate for SCA and HSP varies between different studies, and this may be influenced not only by the type of NGS approach applied, but also by the criteria adopted to select patients in third-level reference centers. Here we report the results of a retrospective study conducted on a large cohort of HSP/SCA patients referred to us for diagnosis and follow-up over a 14-year period (from 2005 to 2019). Our aims were to estimate the diagnostic yield reached in this HSP and SCA cohorts i) before NGS ii) by NGS gene panels. 


\section{Materials and Methods}

This retrospective study was carried out in compliance with the Helsinki Declaration and the Good Clinical Practice; all patients gave a written informed consent, approved by our ethics committee, authorizing the use of diagnostic data for clinical research purposes about their disease.

It involved a total of 230 consecutive adult patients from 192 unrelated families: 124 SCA (mean age 58.4 years, range 19-86 years) from 102 families and 106 HSPs (mean age 53.4 years, range 18-86 years) from 90 families. All of them were clinically evaluated and diagnosed at our third-level expert center for diagnosis and follow-up for HSPs and cerebellar ataxias in the Latium Region over a 14-year period (from January 2005 until December 2019). Prior to this study, other causes of toxic, immune-mediated, inflammatory, and metabolic ataxias and spastic paraplegia had been ruled out by appropriate clinical tests (Figure 1; Figure 2).

The SCA cohort included 32 ADCA families (31.4\%), 31 ARCA families (30.4\%), and 39 sporadic $(38.2 \%)$. MSA-C patients were not included. Among HSP families, 30/90 $(33.3 \%)$ were AD, $27(30 \%)$ were AR, and $33(36.7 \%)$ sporadic (Table 1$)$.

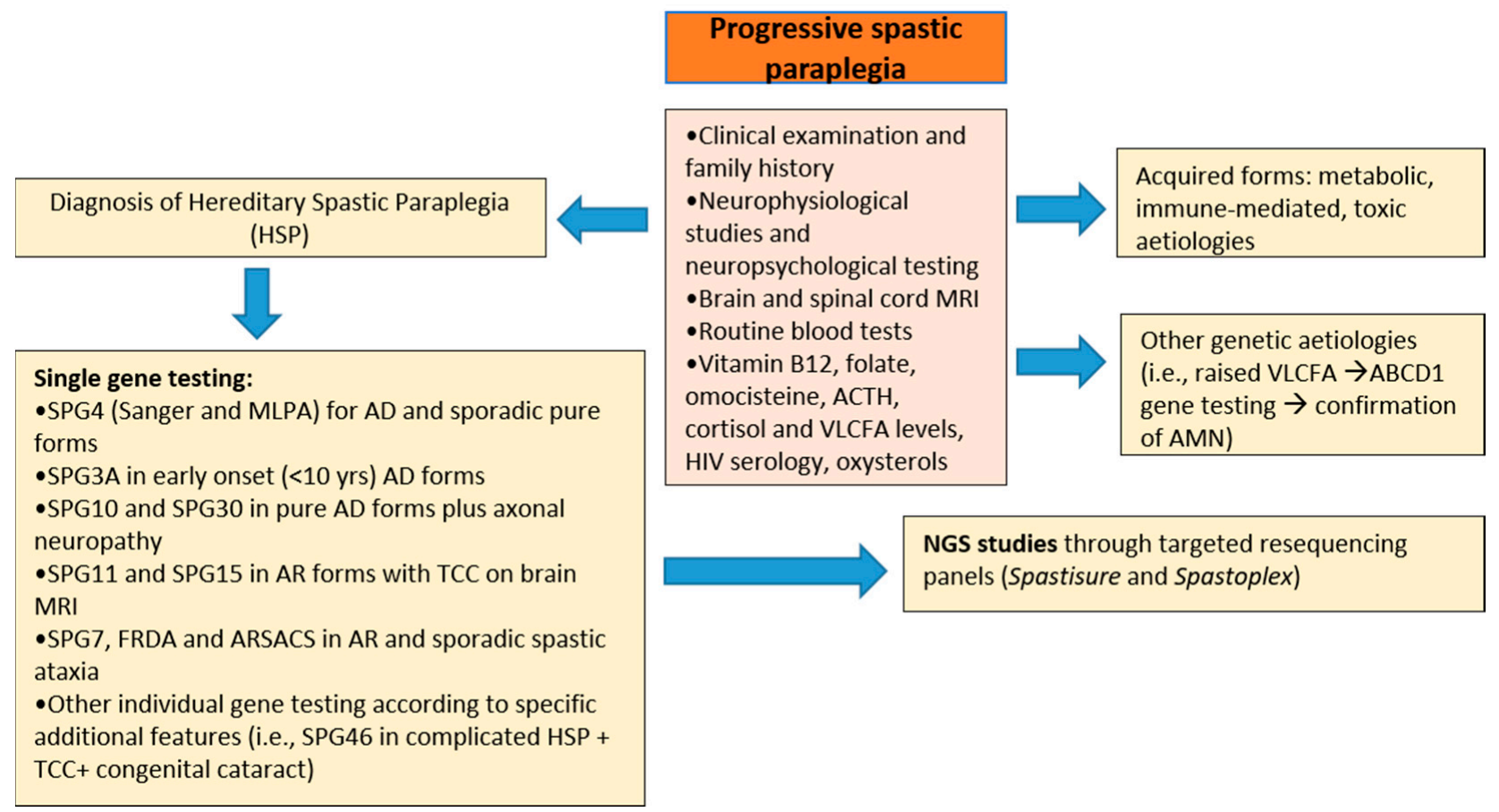

Figure 1. Diagnostic flowchart applied to patients with suspected degenerative progressive spastic paraplegia (HSP) Abbreviations: NGS, Next Generation Sequencing; VLCFA, Very Long Chain Fatty Acids; AD, autosomal dominant; AR, autosomal recessive; TCC, thin corpus callosum; FRDA, Freidreich's Ataxia; ARSACS, Autosomal recessive spastic ataxia of Charlevoix-Saguenay; MLPA, Multiplex Ligation Probe Amplification; HIV, Human Immunodeficiency Virus; AMN, adrenomyeloneuropathy. 


\begin{tabular}{|c|c|c|}
\hline \multirow{3}{*}{ Inherited Cerebellar Ataxias } & $\begin{array}{c}\text { Progressive } \\
\text { Cerebellar Ataxias }\end{array}$ & \\
\hline & \multirow{3}{*}{$\begin{array}{l}\text {-Clinical examination and } \\
\text { family history } \\
\text { • Neurophysiological } \\
\text { studies and } \\
\text { neuropsychological testing } \\
\text { - Brain and spinal cord MRI } \\
\text { - Eye assessment } \\
\text { - Routine blood tests } \\
\text {-Serum Vitamin E, alpha- } \\
\text { phoetum protein, lactate } \\
\text {-Skin/Muscle biopsy with } \\
\text { morphological or } \\
\text { biochemical studies when } \\
\text { suspecting neurometabolic } \\
\text { disorders (i.e., NPC) or } \\
\text { mitochondrial disorders }\end{array}$} & $\begin{array}{l}\text { Other degenerative aetiologies } \\
\text { (MSA) }\end{array}$ \\
\hline & & $\begin{array}{l}\text { Acquired forms: metabolic, } \\
\text { immune-mediated, toxic } \\
\text { aetiologies }\end{array}$ \\
\hline \multirow{2}{*}{$\begin{array}{l}\text { Single gene testing: } \\
\text { - SCA1-2-3-6-7-10-12-17 in AD forms } \\
\text { - SCA1 and SCA2 in sporadic forms } \\
\text { - FRDA and FXTAS (if onset >50 yrs) in AR and } \\
\text { sporadic forms } \\
\text {-ATM, Senataxin, Aprataxin, MRE11, NPC } \\
\text { and AVED in selected patients } \\
\text { - RFC1 (only from 2019) in sporadic and AR } \\
\text { adult onset forms with ataxia and sensory } \\
\text { neuropathy }\end{array}$} & & $\begin{array}{l}\text { Other genetic aetiologies (i.e., } \\
\text { MERRF or other mitochondrial } \\
\text { encephalomyopathies) }\end{array}$ \\
\hline & $\begin{array}{l}\text { NGS studies through } \\
\text { 3.0) }\end{array}$ & sequencing panels (Ataxome 2.0 and \\
\hline
\end{tabular}

Figure 2. Diagnostic flowchart applied at the suspected degenerative cerebellar ataxia patients. Abbreviations: SCA, SpinoCerebellar Ataxia; FRDA, Friedreich's Ataxia; FXTAS, Fragile X-associated tremor/ataxia syndrome; AD, autosomal dominant; AR, autosomal recessive; ATM, ataxia-telangiectasia mutated; NPC, Niemann-Pick disease type C; AVED, Ataxia with vitamin E deficiency; RFC1, replication factor complex 1; NGS, Next-Generation Sequencing.

Table 1. Genetic diagnosis reached at the first-tier screening. Abbreviations: HSP, Hereditary Spastic Paraplegia; CA, Cerebellar Ataxia; AD, autosomal dominant; AR, autosomal recessive; SGT, single gene testing.

\begin{tabular}{|c|c|c|c|}
\hline \multicolumn{4}{|c|}{ HSP (90 Families) } \\
\hline & AD 30/90 (33.3\%) & AR $27 / 90(30 \%)$ & Sporadic 33/90 (36.7\%) \\
\hline diagnosis reached & $17 / 30(56.7 \%)$ & $15 / 27(55.5 \%)$ & $7 / 33(21.2 \%)$ \\
\hline genetic diagnosis & $\begin{array}{l}16 \text { SPG4/30 SPG4 SGT } \\
1 \text { SPG10/1 SPG10 SGT }\end{array}$ & $\begin{array}{c}6 \text { SPG11/8 SPG11 SGT } \\
2 \text { SPG15/2 SPG15 SGT } \\
2 \text { SPG7/5 SPG7 SGT } \\
1 \text { SPG5/1 SPG5 SGT } \\
1 \text { SPG35/1 SPG35 SGT } \\
1 \text { SPG45/1 SPG45 SGT } \\
1 \text { SPG56/4 SPG56 SGT } \\
1 \text { MT-ND3/1 mtDNA } \\
\text { sequencing }\end{array}$ & $\begin{array}{c}5 \text { SPG4/33 SPG4 SGT } \\
1 \text { SPG7 / } 6 \text { SPG7 SGT } \\
1 \text { OPA1/1 OPA1 SGT }\end{array}$ \\
\hline \multicolumn{4}{|c|}{ CA (102 Families) } \\
\hline & $\mathrm{AD} 32 / 102(31.4 \%)$ & AR 31/102 (30.4\%) & Sporadic 39/102 (38.2\%) \\
\hline diagnosis reached & $24 / 32(75 \%)$ & $16 / 31(51.6 \%)$ & $13 / 39(33.3 \%)$ \\
\hline genetic diagnosis & $\begin{array}{l}15 \text { SCA2/32 SCA2 SGT } \\
5 \text { SCA1/32 SCA1 SGT } \\
2 \text { SCA3/32 SCA3 SGT } \\
1 \text { SCA6/32 SCA6 SGT } \\
1 \text { SCA7/32 SCA7 SGT }\end{array}$ & $\begin{array}{c}10 \text { FRDA/31 FRDA SGT } \\
3 \text { SACS/4 SACS SGT } \\
1 \text { ATM/1 ATM SGT } \\
1 \text { AVED/1 TTPA SGT } \\
1 \text { CANVAS/2 RFC1 SGT }\end{array}$ & $\begin{array}{c}4 \text { FRDA/39 FRDA SGT } \\
3 \text { SPG7/6 SPG7 SGT } \\
2 \text { CANVAS/20 RFC1 SGT } \\
1 \text { SACS/7 SACS SGT } \\
\text { 1 SCA1/39 SCA1 SGT } \\
1 \text { SCA2/39 SCA2 SGT } \\
1 \text { FXTAS/6 FMR1 SGT }\end{array}$ \\
\hline
\end{tabular}

The diagnostic protocol for cerebellar ataxias and HSP, illustrated in Figure 1; Figure 2, respectively, included brain and spine MRI, EEG, EMG and nerve conduction studies, 
motor- and sensory-evoked potentials, ophthalmological, audiological, and neuropsychological evaluation. Routine blood tests also included vitamin B12, homocysteine and folate plasma levels; other tests performed were serum vitamin E, lactate and alpha-foetum protein levels, plasma ceruloplasmin, and copper and iron determinations. ACTH, cortisol, and plasma very long-chain fatty acid (VLCFA) levels were also assessed in all males with spastic ataxia with onset $<40$ years of age. In selected cases, skin or muscle biopsy was performed when Niemann Pick type $C$ or mitochondrial diseases were suspected, respectively, and lysosomal HEXA and B activities in leukocytes to rule out Sandhoff disease. Immunoblotting studies of ATM, senataxin, aprataxin, and MRE11 proteins were done in all ataxic cases showing clinical oculomotor apraxia and/or raised serum alpha-fetoprotein levels.

Leukocyte total DNA was isolated from blood samples after informed consent and processed for primary diagnostic purposes at the Medical Genetics Laboratory of Fondazione Policlinico A. Gemelli (Rome).

For HSP patients, first-tier individual gene screening (Figure 1) included analysis of SPAST (SPG4) gene by direct Sanger sequencing and Multiplex Ligation Probe Amplification (MLPA) in all AD or sporadic pure forms, SPG3A in all AD cases with onset $<10$ years, and search for variants in SPG10 and SPG30 either in pure AD forms or those complicated by axonal neuropathy. Direct capillary sequencing of the SPG11 and SPG15 genes was done in all AR-HSP with TCC on brain MRI.

In cases with sporadic or documented AR inheritance of spastic ataxia, we sought pathological GAA expansion of the first intron of the FXN gene and direct sequencing of the SACS and SPG7 genes.

In the first-tier screening (Figure 2), all AD SCA patients underwent screening for expanded repeats at the AD-SCA1-2-3-6-7-10-12-17. ARCA and sporadic SCA were screened for expanded repeats at FRDA and FTXAS (if onset $>50$ years) loci; sporadic SCA performed SCA1 and SCA2 testing as well (as these are the most frequent AD-SCA in Italy). DNA samples that tested negative were sent for further diagnostic testing by Sanger sequencing of individual SCA or HSP genes, according to the suspicion emerging from results of the diagnostic assessment (i.e., TTPA in the case of very low or undetectable serum vitamin E, ATM in the case of raised alfa-fetoprotein levels, direct sequencing of the SCA28/AFG3L2 gene in patients with autosomal dominant spastic ataxia) either to the Molecular Medicine Laboratory, IRCCS Stella Maris, Pisa, or the Laboratory of Molecular medicine Ospedale Pediatrico Bambino Gesù, Rome. More recently, late-onset sporadic or ARCA patients with sensory ataxia were also tested for biallelic AAGGG expansion in RFC1 associated with CANVAS [29].

At the time of this writing, 32 patients completed NGS investigations using targeted multigene panels (TRPs) designed for ataxia (ATAXOME 2.0 and 3.0, which contained 273 and 285 genes, respectively), HSP (Spastoplex with 72 genes and Spastisure with 118), and leukodystrophies. DNA samples were analyzed either at the Fondazione Stella Maris IRCCS (28 pts) or at the Ospedale Pediatrico Bambino Gesù (4 pts). Details about NGS methodology, accuracy of the specific TRP methodology, and customized bioinformatics pipelines have been previously described [25,30-32]. Variants were classified as pathogenic, likely pathogenic, of uncertain significance (VUS), likely benign or benign according to the criteria established by the ACMG standards and guidelines [33]. All variants were further validated by capillary Sanger sequencing, and family segregation studies were carried out if DNA from close relatives was available.

\section{Results}

Eighty-nine out of 192 HSP/SCA families (46.3\%) received a genetic diagnosis at the first-tier screening.

In total, 39/90 (43.3\%) HSP probands were genetically characterized (Table 1 and Figure 3); the diagnostic rate was 56.7\% in AD-HSP (17/30 families), and SPG4 was the most frequent form (16/17), with a novel SPG10 pathogenic variant found in one family [34]. Regarding AR-HSP, a genetic diagnosis was made in 15/27 families (55.5\%): in the SPG11 
gene, mutations were the prevalent genetic etiology (six families, $42.8 \%$ ), followed by SPG15 and SPG7 (six families each), SPG5, SPG35, SPG46, and SPG56 [35] (one patient each). A 35-year-old female with severe spastic paraplegia and optic atrophy, included among AR cases as one deceased sister was similarly affected, carried a pathogenic variant affecting a conserved position in the mtDNA-encoded gene MT-ND3 gene. Her muscle biopsy showed a biochemical complex I deficiency, and no ragged red fibers (RRFs). Seven patients out of 33 sporadic HSPs (21.2\%) received a genetic diagnosis: five harbored mutations in SPAST, one case had biallelic variants in SPG7, and a young woman manifesting with HSP + early onset optic atrophy harbored a nonsense variant in OPA1.

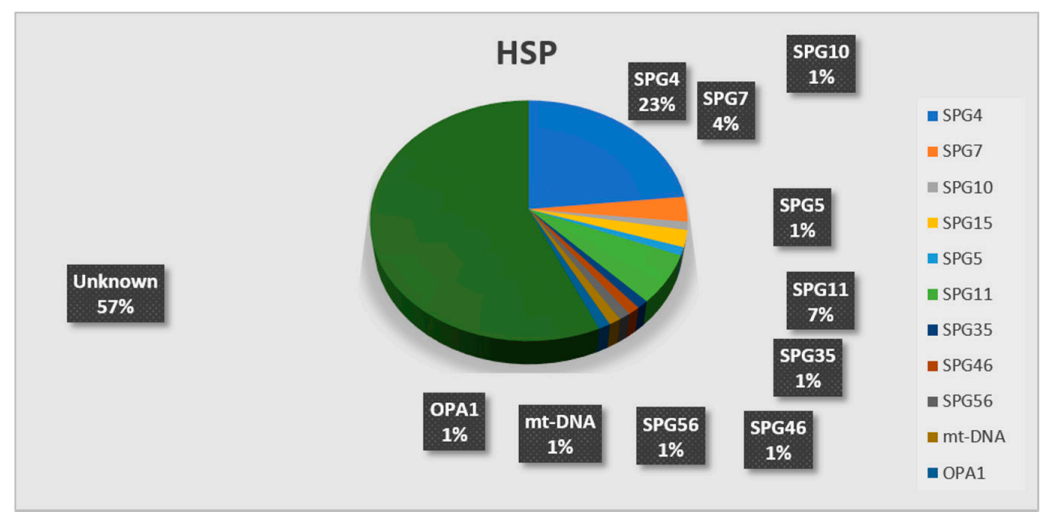

Figure 3. The pie-chart displays the results of individual gene screening in the HSP cohort, with an overall diagnostic yield of $43 \%$. In black boxes, the relative percentages for each molecular diagnosis are reported; SPG4 was the most common HSP form, followed by SPG11 and SPG7.

Regarding SCAs, a genetic diagnosis was achieved in 53/102 families (52\%) (Table 1 and Figure 4). Specifically, 24/32 AD forms (75\%) were polyQ SCA, with SCA2 being the most frequent (15 families), followed by SCA1 (five families), SCA3 (two families), SCA6, and SCA7 (one family each). One SCA3 patient and the SCA7 patient were not of Italian ancestry. Among the 31 ARCA families, 16 (51.6\%) received a genetic diagnosis. In this case, FRDA was the most frequent etiology (10 families), followed by SACS (3 families), and one case each received a molecular diagnosis of ATM, AVED, and CANVAS. The AVED family was of Moroccan origin. Finally, $13 / 39$ sporadic patients with ataxia (33.3\%) received a genetic diagnosis as follows: four with homozygous intron 1 expansion in FXN; three biallelic variants in SPG7, 2 CANVAS, 1 SACS, 1 SCA1, 1 SCA2; and one FXTAS.

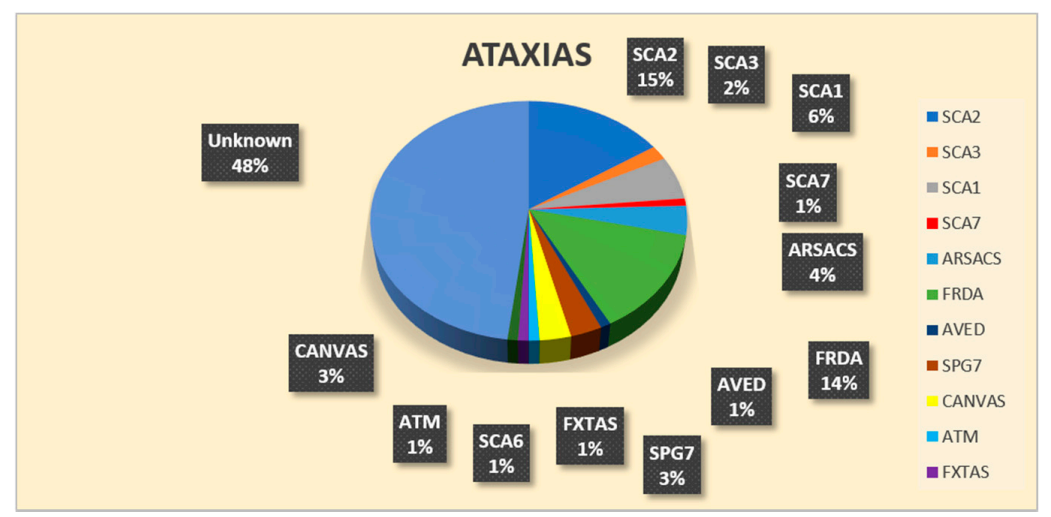

Figure 4. Pie-chart showing the results of individual gene screening on the group degenerative ataxias. A molecular diagnosis was assessed in $52 \%$ of the whole cohort. In black boxes the relative percentages for each molecular diagnosis are reported; SCA2 and Friedreich's ataxia were the most common genetic subtypes. 


\section{NGS Studies}

Until now, TRP-NGS based molecular screening was completed in 32/103 of our undiagnosed families, including 24 with cerebellar or spastic ataxia, and 8 with pure or complicated (Figure 5). Overall, 11/32 cases (34.4\%) had a confirmatory molecular diagnosis: $7 / 24(29.2 \%)$ had cerebellar ataxia, and $4 / 8$ (50\%) presented HSP. Eleven of the identified variants classified as likely pathogenic were novel.

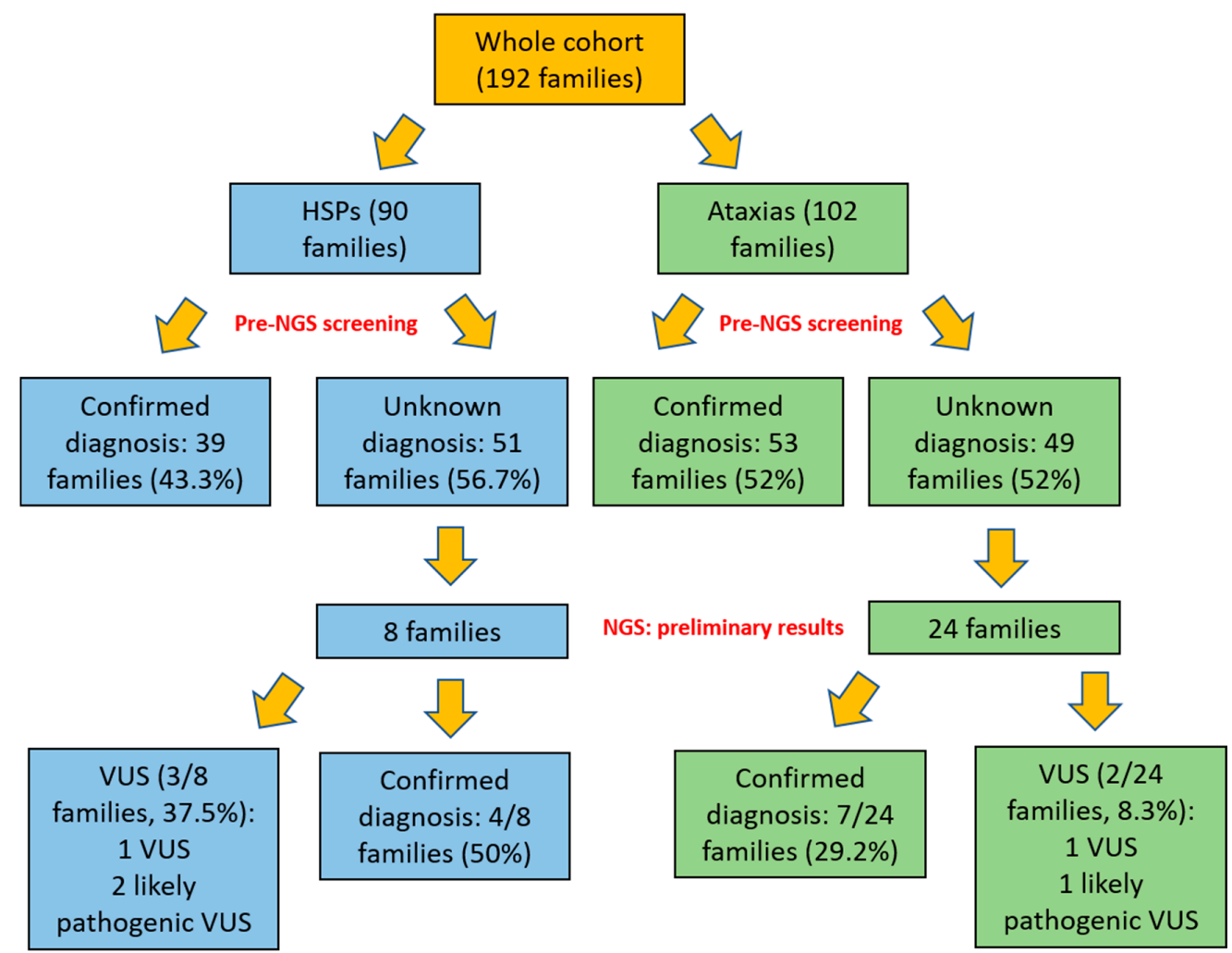

Figure 5. Schematic representation of the results of the diagnostic route in our cohort of SCA and HSP cases.

In addition, two further patients with ataxia and three with HSP showed VUS in six genes (Table 2) five of which with a possible pathogenic significance, deserving further investigations to assess a disease-related role.

Table 2 summarizes clinical and molecular findings of these 16 patients. Six patients (\#1, \#2, \#5, \#11,\#12,\#13) have been already described [30,32,36]. Clinico-diagnostic features are reported in detail in a supplementary file. 


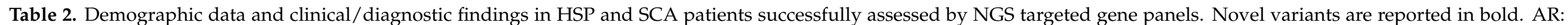

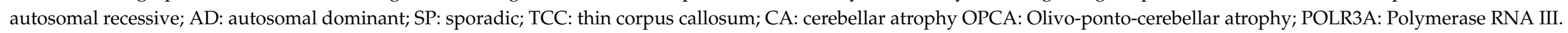
Related references are reported in brackets. The line in bold divides HSP and ataxias cases.

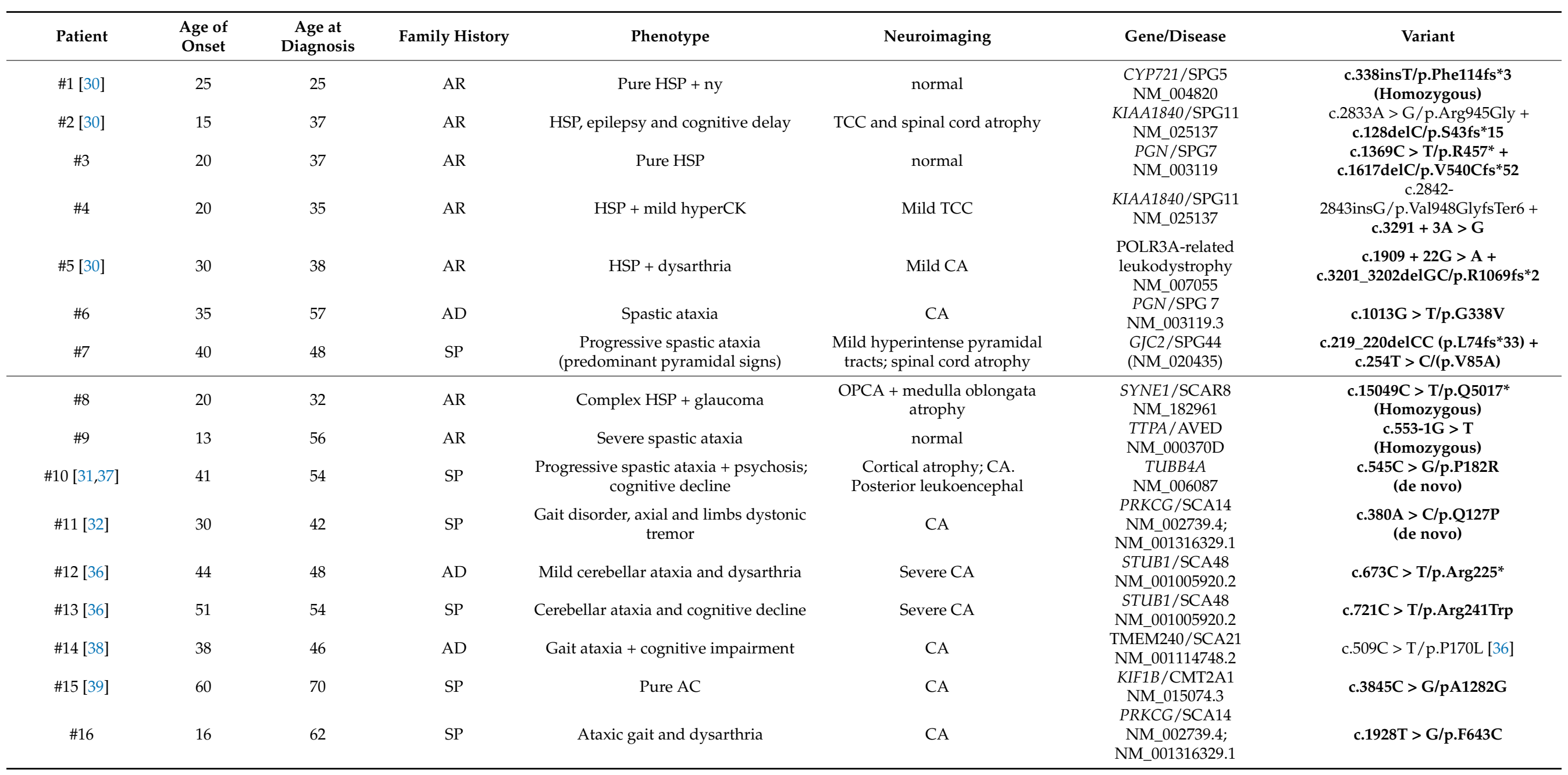




\section{Discussion}

This retrospective study aimed to assess the value of our clinical-diagnostic assessment in patients with suspected HSP or SCA either before or, although on limited data, following the advent of targeted NGS panels in the genetic characterization of these two neurodegenerative forms.

In our first-tier screening based on individual gene testing, $46 \%$ of 205 families received a diagnosis, specifically $43.3 \%$ of HSP and $50 \%$ of the cerebellar ataxias. SPG 4 form was the most frequent among AD-HSP, and the SPG11 form among AR-HSP. The diagnostic rate was lower, but relevant $(21.21 \%)$ also in sporadic HSPs. Among cerebellar ataxias, ADCA showed a higher diagnostic rate $(64.5 \%)$, mostly due to polyQ AD-SCA. Fifty-two percent of ARCA was also genetically diagnosed, and FRDA was the most frequent form, followed by ARSACS. Sporadic SCAs showed a diagnostic rate of 33.3\%; FRDA and SPG7 were equally prevalent in this subcohort, followed by ARSACS and CANVAS.

These results support the consistency and accuracy of our diagnostic protocol specifically designed for SCAs and HSPs. In fact, a recent review indicated that the number of families without a genetic diagnosis after systematic gene testing ranged from 33 to $92 \%$ in the ADCA group, $40-46 \%$ in the ARCA, $45-67 \%$ in the AD-HSP, and 71-82\% in the AR-HSP groups [1].

Remarkably, among diagnosed HSP families, we did not include those that manifested spastic paraparesis as a predominant feature, in whom we addressed by our diagnostic protocol other genetic diagnoses, including one family affected by severe MTHFR deficiency [40], and two unrelated males with adrenomyeloneuropathy. On the other hand, we also included three patients who recently tested positive to the biallelic expanded pentanucleotide in RFC1 associated with CANVAS.

The advent of the "next-generation sequencing era" has positively changed the perspective for clinical research and diagnosis also regarding SCA and HSP [24,25,41,42]; a recent review of the literature of NGS-based studies in ataxias assessed an average diagnostic rate of $17 \%$ for TRPs, increasing to $34 \%$ when including VUS with a potential pathogenic role. As expected, WES resulted in a higher average diagnostic rate (36\%, range $21-46 \%)$, again with higher rates (average 53\%) if VUS of potential pathogenic significance were also included [25].

Regarding HSP, two distinct NGS panels including over $100 \mathrm{HSP}$ / ataxia genes applied to a very large cohort HSP patients, who obtained a positive diagnostic yield of $29 \%$, with VUS of possible pathogenic significance found in an additional $36 \%$ of cases [30].

Comparing these data with our preliminary findings by TRPs, we obtained a good diagnostic rate in ataxias $(29 \%, 7 / 24$ cases), being even higher (50\% $4 / 8)$ in HSP without including VUS.

Table 3 illustrates diagnostic rates of the more recent and largest NGS studies along with our work.

Table 3. Diagnostic yield comparison between results of this study and recent literature works on HSP and CA cohorts through NGS techniques. References numbers are in brackets. Abbrevations: HSP, Hereditary Spastic Paraplegia; CA, Cerebellar Ataxias; TGP, Targeted resequencing panels; TES, Targeted exome sequencing; WES, whole-exome sequencing.

\begin{tabular}{|c|c|c|c|}
\hline References & Subjects & Diagnostic Rate HSP & Diagnostic Rate CA \\
\hline $\begin{array}{l}\text { Our data } \\
\text { TGP }\end{array}$ & 32 & $50 \%$ & $29.2 \%$ \\
\hline D'Amore et al. 2018 [30] TGP & 239 & $29 \%$ & \\
\hline $\begin{array}{c}\text { Nemeth et al. } 2013 \text { [41] } \\
\text { TGP }\end{array}$ & 50 & & $18 \%$ \\
\hline $\begin{array}{c}\text { Coutelier et al. } 2018 \text { [43] } \\
\text { TES }\end{array}$ & 319 & & $28.5 \%$ \\
\hline $\begin{array}{c}\text { Lu et al. } 2018 \text { [44] } \\
\text { TGP }\end{array}$ & 55 & $61.8 \%$ & \\
\hline $\begin{array}{l}\text { Burguez et al. } 2017 \text { [8] } \\
\text { TGP }\end{array}$ & 29 & $48.3 \%$ & \\
\hline $\begin{array}{c}\text { Lynch et al. } 2016 \text { [45] } \\
\text { TES + TGP }\end{array}$ & 40 & $52.5 \%$ & \\
\hline $\begin{array}{c}\text { Kara et al. } 2016 \text { [46] } \\
\text { TES + WES }\end{array}$ & 97 & $49 \%$ & \\
\hline $\begin{array}{c}\text { Schule et al. } 2016 \text { [11] } \\
\text { TGP + WES }\end{array}$ & 608 & $46 \%$ & \\
\hline $\begin{array}{c}\text { Fogel et al. } 2014 \text { [28] } \\
\text { TES }\end{array}$ & 76 & & $21 \%$ \\
\hline
\end{tabular}


As expected, studies applying WES/MLPA only to familial HSP or SCA cases reached higher diagnostic yields (50-60\%) [8,47], even up to 90\% when regarding only AD-HSP [48]. Conversely, similar studies obtained a lower diagnostic rate (33\%) in cohorts of previously undiagnosed patients and also including sporadic cases [8].

However, a detailed clinical assessment still plays a significant role, as supported by recent works: (i) a direct high-throughput next-generation approach using Trusight obtained a diagnostic rate of 50\% [8], which in fact increased to $70 \%$ when applied to wellselected HSP patients negative to previous genetic screenings [8,45]; (ii) a NGS multigene panel-based molecular screening assessed in 50 ataxic patients tested negative for SCA1, -2, $-3,-6$, and -7 , and Friedreich ataxia had an overall detection rate of $18 \%$, being lower $(8.3 \%)$ in adult-onset forms, higher $(40 \%)$ in childhood or adolescent-onset progressive disorders, and highest (75\%) in those with adolescent-onset and a positive family history [41].

\section{Conclusions}

In conclusion, results from our work would support the role of experienced clinicians in the diagnostic assessment of SCA/HSP patients to reach a conclusive molecular definition, even in "the next generation era", as they can offer a precious contribution to geneticists both in the patients' selection and in the critical evaluation of the gene variants prioritized in silico.

Supplementary Materials: The following are available online at https:/ /www.mdpi.com/2076-342 5/11/2/246/s1, Supplementary File: Description of cases diagnosed by Next-Generation Sequencing.

Author Contributions: Conceptualization, G.S.; methodology, A.T., L.T., G.Z., C.A., M.B., M.G.P., F.M.S., G.S.; formal analysis, V.R., S.R., A.T., L.T., G.Z., C.A., A.P., M.B., M.G.P., F.M.S., G.S.; investigation, A.T., L.T., G.Z., C.A., M.B., M.G.P., F.M.S.; data curation, V.R., S.R., T.F.N., A.P., F.M.S., G.S.; writing—original draft preparation, V.R., G.S.; writing—review and editing, S.R., F.M.S., G.S.; visualization, F.M.S.; supervision, F.M.S., G.S. All authors have read and agreed to the published version of the manuscript.

Funding: This research received no external funding.

Institutional Review Board Statement: Storage/handling of genetic and personal data complied with Italian National Health Institute (ISS) regulations on ethical and biomedical research and with relevant current legislation. All the participants, including relatives involved in segregation studies, provided written informed consent for their genetic studies approved by the Research Committee of IRCCS Fondazione Policlinico A Gemelli (MOD.147, Vers. 1.1. 25/06/2019), and in accordance both with Italian National Health System guidelines and with the Declaration of Helsinki.

Informed Consent Statement: Informed consent was obtained from all subjects involved in the study.

Data Availability Statement: The data that support the findings of this study are available from the corresponding author, G.S., upon reasonable request.

Acknowledgments: We thank Glen W. McWilliams, MD, Chief of Robotic Surgery James J. Peters VAMC, for revising the English form of the manuscript. S.R. received a fellowship partially granted by the A.I. Vi.P.S. Onlus (Associazione Italiana Vivere la Paraparesi Spastica). G.Z. is a member of the European Reference Network for Rare Neurological Diseases_Project ID No 739510 The other authors have no disclosures about this work.

Conflicts of Interest: The authors declare no conflict of interest.

\section{References}

1. Fink, J.K. Hereditary spastic paraplegia: Clinico-pathologic features and emerging molecular mechanisms. Acta Neuropathol. 2013, 126, 307-328. [CrossRef]

2. Ruano, L.; Melo, C.; Silva, M.C.; Coutinho, P. The global epidemiology of hereditary ataxia and spastic paraplegia: A systematic review of prevalence studies. Neuroepidemiology 2014, 42, 174-183. [CrossRef]

3. Boutry, M.; Morais, S.; Stevanin, G. Update on the genetics of spastic paraplegias. Curr. Neurol. Neurosci. Rep. 2019, 19, 18. [CrossRef] 
4. Tesson, C.; Koht, J.; Stevanin, G. Delving into the complexity of hereditary spastic paraplegias: How unexpected phenotypes and inheritance modes are revolutionizing their nosology. Hum. Genet. 2015, 134, 511-538. [CrossRef] [PubMed]

5. Hensiek, A.; Kirker, S.; Reid, E. Diagnosis, investigation and management of hereditary spastic paraplegias in the era of next-generation sequencing. J. Neurol. 2015, 262, 1601-1612. [CrossRef]

6. Parodi, L.; Coarelli, G.; Stevanin, G.; Brice, A.; Durr, A. Hereditary ataxias and paraparesias: Clinical and genetic update. Curr Opin. Neurol. 2018, 31, 462-471. [CrossRef]

7. Racis, L.; Storti, E.; Pugliatti, M.; Agnetti, V.; Tessa, A.; Santorelli, F.M. Novel SPAST deletion and reduced DPY30 expression in a spastic paraplegia type 4 kindred. BMC Med Genet. 2014, 15, 39. [CrossRef]

8. Burguez, D.; Polese-Bonatto, M.; Scudeiro, L.A.J.; Björkhem, I.; Schöls, L.; Jardim, L.B.; Matte, U.; Saraiva-Pereira, M.L.; Siebert, M.; Saute, J.A.M. Clinical and molecular characterization of hereditary spastic paraplegias: A next-generation sequencing panel approach. J. Neurol. Sci. 2017, 383, 18-25. [CrossRef]

9. Dong, E.-L.; Wang, C.; Wu, S.; Lu, Y.-Q.; Lin, X.-H.; Su, H.-Z.; Zhao, M.; He, J.; Ma, L.-X.; Wang, N.; et al. Clinical spectrum and genetic landscape for hereditary spastic paraplegias in China. Mol. Neurodegener. 2018, 13, 1-14. [CrossRef] [PubMed]

10. Chrestian, N.; Dupré, N.; Gan-Or, Z.; Szuto, A.; Chen, S.; Venkitachalam, A.; Brisson, J.-D.; Warman-Chardon, J.; Ahmed, S.; Ashtiani, S.; et al. Clinical and genetic study of hereditary spastic paraplegia in Canada. Neurol. Genet. 2017, 3, e122. [CrossRef] [PubMed]

11. Schüle, R.; Wiethoff, S.; Martus, P.; Karle, K.N.; Otto, S.; Klebe, S.; Klimpe, S.; Gallenmüller, C.; Kurzwelly, D.; Henkel, D.; et al. Hereditary spastic paraplegia: Clinicogenetic lessons from 608 patients. Ann. Neurol. 2016, 79, 646-658. [CrossRef] [PubMed]

12. Stevanin, G.; Azzedine, H.; Denora, P.; Boukhris, A.; Tazir, M.; Lossos, A.; SPATAX Consortium; Rosa, A.L.; Lerer, I.; Hamri, A.; et al. Mutations in SPG11 are frequent in autosomal recessive spastic paraplegia with thin corpus callosum, cognitive decline and lower motor neuron degeneration. Brain 2007, 131, 772-784. [CrossRef]

13. Esteves, T.; Durr, A.; Mundwiller, E.; Loureiro, J.L.; Boutry, M.; Gonzalez, M.A.; Gauthier, J.; El-Hachimi, K.H.; Depienne, C.; Muriel, M.-P.; et al. Loss of association of REEP2 with membranes leads to hereditary spastic paraplegia. Am. J. Hum. Genet. 2014, 94, 268-277. [CrossRef] [PubMed]

14. Coutelier, M.; Goizet, C.; Durr, A.; Habarou, F.; Morais, S.; Dionne-Laporte, A.; Tao, F.; Konop, J.; Stoll, M.; Charles, P.; et al. Alteration of ornithine metabolism leads to dominant and recessive hereditary spastic paraplegia. Brain 2015, 138, $2191-2205$. [CrossRef]

15. Erlich, Y.; Edvardson, S.; Hodges, E.; Zenvirt, S.; Thekkat, P.; Shaag, A.; Dor, T.; Hannon, G.J.; Elpeleg, O. Exome sequencing and disease-network analysis of a single family implicate a mutation in KIF1A in hereditary spastic paraparesis. Genome Res. 2011, 21, 658-664. [CrossRef]

16. Lee, J.R.; Srour, M.; Kim, D.; Hamdan, F.F.; Lim, S.H.; Brunel-Guitton, C.; Décarie, J.C.; Rossignol, E.; Mitchell, G.A.; Schreiber, A.; et al. De novo mutations in the motor domain of KIF1A cause cognitive impairment, spastic paraparesis, axonal neuropathy, and cerebellar atrophy. Hum. Mutat. 2015, 36, 69-78. [CrossRef] [PubMed]

17. Sánchez-Ferrero, E.; Coto, E.; Beetz, C.; Gamez, J.; Corao, A.; Diaz, M.; Esteban, J.; Del Castillo, E.; Moris, G.; Infante, J.; et al. SPG7mutational screening in spastic paraplegia patients supports a dominant effect for some mutations and a pathogenic role for p.A510V. Clin. Genet. 2013, 83, 257-262. [CrossRef] [PubMed]

18. Klebe, S.; Depienne, C.; Gerber, S.; Challe, G.; Anheim, M.; Charles, P.; Fedirko, E.; Lejeune, E.; Cottineau, J.; Brusco, A.; et al. SPG7 Spastic paraplegia gene 7 in patients with spasticity and/or optic neuropathy. Brain 2012, 135 Pt 10, 2980-2993. [CrossRef]

19. Rydning, S.L.; Dudesek, A.; Rimmele, F.; Funke, C.; Krüger, S.; Biskup, S.; Vigeland, M.D.; Hjorthaug, H.S.; Sejersted, Y.; Tallaksen, C.; et al. A novel heterozygous variant inERLIN2causes autosomal dominant pure hereditary spastic paraplegia. Eur. J. Neurol. 2018, 25, 943-e71. [CrossRef]

20. Klockgether, T.; Mariotti, C.; Paulson, H.L. Spinocerebellar ataxia. Nat. Rev. Dis. Prim. 2019, 5, 24. [CrossRef] [PubMed]

21. Anheim, M.; Tranchant, C.; Koenig, M. The autosomal recessive cerebellar ataxias. N. Engl. J. Med. 2012, 366, 636-646. [CrossRef]

22. Beaudin, M.; Klein, C.J.; Rouleau, G.A.; Dupré, N. Systematic review of autosomal recessive ataxias and proposal for a classification. Cerebellum Ataxias 2017, 4, 1-12. [CrossRef]

23. Buermans, H.P.; den Dunnen, J.T. Next generation sequencing technology: Advances and applications. Biochim. Biophys. Acta 2014, 1842, 1932-1941. [CrossRef]

24. Shribman, S.; Reid, E.; Crosby, A.H.; Houlden, H.; Warner, T.T. Hereditary spastic paraplegia: From diagnosis to emerging therapeutic approaches. Lancet Neurol. 2019, 18, 1136-1146. [CrossRef]

25. Galatolo, D.; Tessa, A.; Filla, A.; Santorelli, F.M. Clinical application of next generation sequencing in hereditary spinocerebellar ataxia: Increasing the diagnostic yield and broadening the ataxia-spasticity spectrum. A retrospective analysis. Neurogenetics 2018, 19, 1-8. [CrossRef] [PubMed]

26. Synofzik, M.; Schüle, R. Overcoming the divide between ataxias and spastic paraplegias: Shared phenotypes, genes, and pathways. Mov. Disord. 2017, 32, 332-345. [CrossRef]

27. Novarino, G.; Fenstermaker, A.G.; Zaki, M.S.; Hofree, M.; Silhavy, J.L.; Heiberg, A.D.; Abdellateef, M.; Rosti, B.; Scott, E.; Mansour, L.; et al. Exome sequencing links corticospinal motor neuron disease to common neurodegenerative disorders. Science 2014, 343, 506-511. [CrossRef] [PubMed] 
28. Fogel, B.L.; Lee, H.; Deignan, J.L.; Strom, S.P.; Kantarci, S.; Wang, X.; Quintero-Rivera, F.; Vilain, E.; Grody, W.W.; Perlman, S.; et al. Exome sequencing in the clinical diagnosis of sporadic or familial cerebellar ataxia. JAMA Neurol. 2014, 71, 1237-1246. [CrossRef] [PubMed]

29. Cortese, A.; Simone, R.; Sullivan, R.; Vandrovcova, J.; Tariq, H.; Yau, W.Y.; Humphrey, J.; Jaunmuktane, Z.; Sivakumar, P.; Polke, J.; et al. Biallelic expansion of an intronic repeat in RFC1 is a common cause of late-onset ataxia. Nat. Genet. 2019, 51, 649-658. [CrossRef] [PubMed]

30. D'Amore, A.; Tessa, A.; Casali, C.; Dotti, M.T.; Filla, A.; Silvestri, G.; Antenora, A.; Astrea, G.; Barghigiani, M.; Battini, R.; et al. Next generation molecular diagnosis of hereditary spastic paraplegias: An Italian cross-sectional study. Front. Neurol. 2018, 9. [CrossRef] [PubMed]

31. Tonduti, D.; Aiello, C.; Renaldo, F.; Dorboz, I.; Saaman, S.; Rodriguez, D.; Fettah, H.; Elmaleh-Bergès, M.; Biancheri, R.; Barresi, S.; et al. TUBB4A-related hypomyelinating leukodystrophy: New insights from a series of 12 patients. Eur. J. Paediatr. Neurol. 2016, 20, 323-330. [CrossRef]

32. Riso, V.; Rossi, S.; Perna, A.; Nicoletti, T.; Bosco, L.; Zanni, G.; Silvestri, G. NGS-based detection of a novel mutation in PRKCG (SCA14) in sporadic adult-onset ataxia plus dystonic tremor. Neurol. Sci. 2020, 41, 2989-2991. [CrossRef] [PubMed]

33. Richards, S.; Aziz, N.; Bale, S.; Bick, D.; Das, S.; Gastier-Foster, J.; Grody, W.W.; Hegde, M.; Lyon, E.; Spector, E.; et al. Standards and guidelines for the interpretation of sequence variants: A joint consensus recommendation of the American College of Medical Genetics and Genomics and the Association for Molecular Pathology. Genet. Med. 2015, 17, 405-423. [CrossRef]

34. Tessa, A.; Silvestri, G.; De Leva, M.F.; Modoni, A.; Denora, P.S.; Masciullo, M.; Dotti, M.T.; Casali, C.; Melone, M.A.B.; Federico, A.; et al. A novel KIF5A/SPG10 mutation in spastic paraplegia associated with axonal neuropathy. J. Neurol. 2008, 255, 1090-1092. [CrossRef] [PubMed]

35. Masciullo, M.; Tessa, A.; Perazza, S.; Santorelli, F.; Perna, A.; Silvestri, G. Hereditary spastic paraplegia: Novel mutations and expansion of the phenotype variability in SPG56. Eur. J. Paediatr. Neurol. 2016, 20, 444-448. [CrossRef]

36. Lieto, M.; Riso, V.; Galatolo, D.; De Michele, G.; Rossi, S.; Barghigiani, M.; Cocozza, S.; Pontillo, G.; Trovato, R.; Saccà, F.; et al. The complex phenotype of spinocerebellar ataxia type 48 in eight unrelated Italian families. Eur. J. Neurol. 2020, $27,498-505$. [CrossRef] [PubMed]

37. Nahhas, N.; Conant, A.; Hamilton, E.; Curiel, J.; Simons, C.; van der Knaap, M.; Vanderver, A. TUBB4A-Related Leukodystrophy. In GeneReviews ${ }^{\circledR}$ [Internet]; Adam, M.P., Ardinger, H.H., Pagon, R.A., Wallace, S.E., Bean, L.J.H., Stephens, K., Amemiya, A., Eds.; University of Washington: Seattle, WA, USA, 2016; 1993-2020; PMID: 27809427.

38. Delplanque, J.; Devos, D.; Huin, V.; Genet, A.; Sand, O.; Moreau, C.; Goizet, C.; Charles, P.; Anheim, M.; Monin, M.L.; et al. TMEM240 mutations cause spinocerebellar ataxia 21 with mental retardation and severe cognitive impairment. Brain 2014, 137, 2657-2663. [CrossRef]

39. Zhao, C.; Takita, J.; Tanaka, Y.; Setou, M.; Nakagawa, T.; Takeda, S.; Yang, H.W.; Terada, S.; Nakata, T.; Takei, Y.; et al. CharcotMarie-Tooth disease type 2A caused by mutation in a microtubule motor KIF1B-beta. Cell 2001, 105, 587-597, Erratum in 2001, 106, 127. [CrossRef]

40. Perna, A.; Masciullo, M.; Modoni, A.; Cellini, E.; Parrini, E.; Ricci, E.; Donati, A.M.; Silvestri, G. Severe 5,10-methylenetetrahydrofolate reductase deficiency: A rare, treatable cause of complicated hereditary spastic paraplegia. Eur. J. Neurol. $2018,25,602-605$. [CrossRef]

41. Németh, A.H.; Kwasniewska, A.C.; Lise, S.; Schnekenberg, R.P.; Becker, E.B.E.; Bera, K.D.; Shanks, M.E.; Gregory, L.; Buck, D.; Cader, M.Z.; et al. Next generation sequencing for molecular diagnosis of neurological disorders using ataxias as a model. Brain 2013, 136, 3106-3118. [CrossRef]

42. Elert-Dobkowska, E.; Stepniak, I.; Krysa, W.; Ziora-Jakutowicz, K.; Rakowicz, M.; Sobanska, A.; Pilch, J.; Antczak-Marach, D.; Zaremba, J.; Sulek, A. Next-generation sequencing study reveals the broader variant spectrum of hereditary spastic paraplegia and related phenotypes. Neurogenetics 2019, 20, 27-38. [CrossRef] [PubMed]

43. Coutelier, M.; Hammer, M.B.; Stevanin, G.; Monin, M.-L.; Davoine, C.-S.; Mochel, F.; Labauge, P.; Ewenczyk, C.; Ding, J.; Gibbs, J.R.; et al. Efficacy of exome-targeted capture sequencing to detect mutations in known cerebellar ataxia genes. JAMA Neurol. 2018, 75, 591-599. [CrossRef]

44. Lu, C.; Li, L.-X.; Dong, H.-L.; Wei, Q.; Liu, Z.-J.; Ni, W.; Gitler, A.D.; Wu, Z.-Y. Targeted next-generation sequencing improves diagnosis of hereditary spastic paraplegia in Chinese patients. J. Mol. Med. 2018, 96, 701-712. [CrossRef] [PubMed]

45. Lynch, D.S.; Koutsis, G.; Tucci, A.; Panas, M.; Baklou, M.; Breza, M.; Karadima, G.; Houlden, H. Hereditary spastic paraplegia in Greece: Characterisation of a previously unexplored population using next-generation sequencing. Eur. J. Hum. Genet. 2015, 24, 857-863. [CrossRef]

46. Kara, E.; Tucci, A.; Manzoni, C.; Lynch, D.S.; Elpidorou, M.; Bettencourt, C.; Chelban, V.; Manole, A.; Hamed, S.A.; Haridy, N.A.; et al. Genetic and phenotypic characterization of complex hereditary spastic paraplegia. Brain 2016, 139 Pt 7, 1904-1918. [CrossRef]

47. Zhao, M.; Chen, Y.-J.; Wang, M.-W.; Lin, X.-H.; Dong, E.-L.; Chen, W.-J.; Wang, N.; Lin, X. Genetic and clinical profile of chinese patients with autosomal dominant spastic paraplegia. Mol. Diagn. Ther. 2019, 23, 781-789. [CrossRef] [PubMed]

48. Wei, Q.; Dong, H.-L.; Pan, L.-Y.; Chen, C.-X.; Yan, Y.-T.; Wang, R.-M.; Li, H.-F.; Liu, Z.-J.; Tao, Q.-Q.; Wu, Z.-Y. Clinical features and genetic spectrum in Chinese patients with recessive hereditary spastic paraplegia. Transl. Neurodegener. 2019, 8, 1-13. [CrossRef] [PubMed] 